\title{
Prevalence and Histopathologic Study of Lernaea cyprinacea in Two Species of Ornamental Fish (Poecilia latipinna and Xiphophorus helleri) in Kerman, South-East Iran
}

\author{
Güney Doğu İran, Kerman’da İki Tür Süs Balığında (Poecilia latipinna ve Xiphophorus \\ helleri) Lernaea cyprinacea Prevalansı ve Histopatolojik İncelemesi
}

\section{Mohammad Mirzaei}

Department of Pathobiology, Faculty of Veterinary Medicine, Shahid Bahonar University of Kerman, Kerman, Iran

\begin{abstract}
Objective: Lernaeids are crustacean parasites that are globally distributed among freshwater and marine fish. Approximately 110 species of Lernaeids have been divided into 14 genera. The most common species of Lernaeids is Lernaea cyprinacea, which has been transmitted to ornamental fish worldwide. The economic importance of $L$. cyprinacea is increasing because of the epidemic caused by the parasite in most of the ornamental fish breeding centers in different parts of the world. The parasite affects its host's health, decreases growth rate, and causes abnormal metabolic activity. Accumulation of these parasites in some parts of the body causes painful points and has harmful outcomes for the functioning and survival of the host.

Methods: The present study was conducted to examine the prevalence of L. cyprinacea among ornamental fish within 1 year from September-October 2011 to September-October 2012. In total, 3520 fish [3380 mollies (Poecilia latipinna) and 140 swordtails (Xiphophorus helleri)] were collected from 10 fish maintenance and breeding centers in Kerman, Iran.

Results: Of 3520 fish, only 186 fish (5.3\%) were infected with L. cyprinacea, and the remaining fish (94.7\%) were not infected. The swordtails (X. helleri) and mollies (P. latipinna) showed the highest (10.7\%) and the lowest (5.1\%) level of infection, respectively. In other words, there was a significant correlation between species of fish and L. cyprinacea infection $(p<0.05)$. The highest prevalence $(39.4 \%)$ and the lowest prevalence $(0 \%)$ of $L$. cyprinacea were observed during summer and winter, respectively, which can be attributed to the temperature difference between the two seasons. Also, the histopathologic examination of sections revealed some lesions in the epidermis, dermis, and muscles. Conclusion: Considering the existing L. cyprinacea infection in ornamental fish reproduction and breeding centers in Kerman, public knowledge should increase through management methods; physical and chemical treatments should also be applied to inform the public regarding the risk of infection and other internal diseases that may be associated with ornamental fish. (Turkiye Parazitol Derg 2015; 39: 222-6)
\end{abstract}

Keywords: Histopathology, Lernaea cyprinacea, ornamental fish, Iran

Received: 30.10 .2014

Accepted: 20.03.2015

\section{Öz}

Amaç: Lernaeid'ler tatlı su ve deniz balıkları arasında küresel dağılımı gösteren kabuklu parazitlerdir. Yaklaşık 110 tür Lernaeid 14 cinse ayrılmıştır. En yaygın Lernaeid türü her yerde süs balıklarına yaygın şekilde bulaşan Lernaea cyprinacea'dır. L. cyprinacea'nın ekonomik önemi, dünyanın farklı bölgelerinde süs balıkları yetiştiren merkezlerin çoğunda parazitin neden olduğu epidemiler nedeniyle artmaktadır. Parazit, konağın sağlığını etkiler, büyüme hızını düşürür ve anormal metabolik aktiviteye neden olur. Vücudun bazı bölgelerinde bu parazitlerin birikimi ağrılı noktalara neden olur ve konağın işleyişi ve sağkalımı üzerine zararlı sonuçları vardır.

Yöntemler: Bu çalışma Eylül-Ekim 2011'den Eylül-Ekim 2012'ye kadar 1 yıl içinde süs balıkları arasında L. cyprinacea prevalansını incelemek amacıyla yapıldı. Toplamda, 3520 balık [3380 moli balığı (Poecilia latipinna) ve 140 kıııckuyruk (Xiphophorus helleri)], İran, Kerman'da 10 balık bakım ve yetiştirme merkezinden toplandı.

Address for Correspondence / Yazışma Adresi: Dr. Mohammad Mirzaei. E.mail: dr_mirzaie_mo@yahoo.com DOI: $10.5152 /$ tpd.2015.3960

CCopyright 2015 Turkish Society for Parasitology - Available online at www.tparazitolderg.org

CTelif hakkı 2015 Türkiye Parazitoloji Derneği - Makale metnine www.tparazitolderg.org web sayfasından ulaşılabilir. 
Bulgular: 3520 balıktan, sadece 186 balık (\%5.3) Lernaea cyprinacea ile enfekte idi ve kalan balıklar (\%94.7) enfekte değildi. Kılıçkuyruk (Xiphophorus helleri) ve moli balıkları (Poecilia latipinna) sırasıyla, en yüksek (\%10.7) ve en düşük (\%5.1) enfeksiyon seviyesi gösterdi. Bir başka deyişle, balık türleri ve L. cyprinacea enfeksiyonu arasında anlamlı korelasyon vardı $(p<0.05)$. L. cyprinacea için en yüksek prevalans $(\% 39.4)$ ve en düşük prevalans (\%0) sırasıyla yazın ve kışın gözlendi, bu durum iki mevsim arasındaki sıcaklık farkına bağlanabilir. Ayrıca kesitlerin histopatolojik incelemesi epidermis, dermis ve kaslarda bazı lezyonları ortaya koydu.

Sonuç: Kerman'da süs balığı çoğaltma ve yetiştirme merkezlerinde L. cyprinacea enfeksiyonu varlığı göz önüne alındığında, kamuoyunun bilgisi yönetim metotları ile artırılmalıdır ve ayrıca kamuoyunu süs balıkları ile ilişkili olabilecek enfeksiyon riski ve diğer iç hastalıklar hakkında bilgilendirmek amacıyla fiziksel ve kimyasal tedaviler uygulanmalıdır. (Turkiye Parazitol Derg 2015; 39: 222-6)

Anahtar Kelimeler: Histopatoloji, Lernaea cyprinacea, süs balıkları, İran

Geliş Tarihi: 30.10 .2014

Kabul Tarihi: 20.03.2015

\section{INTRODUCTION}

Reproduction and breeding of ornamental fish have remarkably increased in recent decades and are rapidly being developed in various countries because of their beauty, small size, and easy maintenance in minimum space. Infections caused by external parasites are often serious diseases that affect ornamental fish and cause financial losses for this growing industry in intensive breeding systems. The ornamental fish may be infected as the final or the intermediate host during the life cycle of these parasites (1, 2). The Lernaeidae family comprises crustacean parasites with global distribution among freshwater and marine fish. Approximately 110 species of Lernaeids have been divided into 14 genera (3). The most common species of Lernaeids is Lernaea cyprinacea that has been transmitted to ornamental fish in several countries such as North America, Europe, Asia, South Africa, and East Australia (4). The economic importance of Lernaea is increasing because of the epidemic caused by the parasite in most ornamental fish breeding centers in different parts of the world (5). The parasite affects its host's health, decreases growth rate, and causes abnormal metabolic activity. Accumulation of these parasites in some parts of the body makes painful points and has harmful outcomes for the functioning and survival of the host (1). The adult female L. cyprinacea attaches to the skin of some parts of fish, including the head, back, stomach, and tail-related areas. However, they frequently accumulate in the fin (6). Certain species of $L$. cyprinacea aggregate around the eyes and cause the destruction of the eye lens, thereby resulting in blindness. Gill infection causes the localized hyperplasia of the mucosal epithelial tissue and also the stiffening of the proliferous mucosal tissue that may seriously disturb breathing and provide the ground for bacterial and viral infections (7). Lernaea is not limited to a specific host; however, it belongs to a wide range of various species of fish, including the families of angelfish, cyprinidae, salmon, and catfish (8). The host's size is effective in determining the structure of this parasite. Among fish, the frequency and severity of Lernaea infection increase with the age and size of hosts. Older fish provide larger space for the parasite as they grow; consequently, the infection increases (9). Therefore, this study aimed to determine the prevalence, intensity, and frequency of Lernaea, find the correlation between the infection and hosts' size, and compare the level of infection of the two species of the Poeciliidae fish family [mollies (Poecilia latipinna) and swordtails (Xiphophorus helleri)] in ornamental fish breeding centers of Kerman, Iran.

\section{METHODS}

The present study was conducted within 1 year from SeptemberOctober 2011 to September-October 2012. In total, 3520 ornamental fish [3380 mollies ( $P$. latipinna) and 140 swordtails ( $X$. helleri)] were collected from 10 fish maintenance and breeding centers in Kerman, Iran. The fish were caught in the ornamental fish breeding centers using a hand net. Each fish was identified in terms of its species and placed in a plastic container full of water. The fish were examined in order to detect the Lernaea parasite, and after measuring their length, they were left in an aquarium. Then, the parasites were removed from gills, skin, mouth, eyes, fins, and other parts using forceps. The removed parasites were delivered to the laboratory of the Department of Parasitology (School of Veterinary Medicine, Shahid Bahonar University of Kerman) for further analysis. The samples were maintained in $70 \%$ ethanol and then cleared in lactophenol. Using an optical microscope, the cleared samples were analyzed, and the genus and species of parasites were identified using the diagnostic key (10). Tissue samples were taken and fixed in $10 \%$ neutral buffered formalin for histopathological examination. Formalin-fixed samples were processed by the standard paraffin wax technique; sections with a thickness of 5 $\mu \mathrm{m}$ were cut and stained with hematoxylin and eosin (H\&E) and examined with a routine light microscope.

The prevalence, intensity, and frequency of the infection among fish were recorded. The results were analyzed using the statistical chi-square test and SPSS (SPSS Inc., Chicago, Illinois, United States) 18 software.

\section{RESULTS}

In total, two species of Poeciliidae ornamental fish [mollies ( $P$. latipinna) and swordtails (X. helleri)] were analyzed in terms of Lernaea infection. Approximately 142 L. cyprinacea parasites were collected, and a minimum of one and a maximum of six parasites were detected on the body of fish. Of 3520 fish, only 186 fish (5.3\%) were infected with L. cyprinacea (Figure 1, 2) and the remaining fish (94.7\%) were not. Mean intensity of infection was $76.3 \%$.

The number of fish infected with L. cyprinacea and the prevalence of infection in two species of Poeciliidae family are shown in Table 1. Severe lesions, such as sores, bleeding, and lymph nodes, were clearly visible in infected fish. Swordtails (X. helleri) and mollies (P. latipinna) showed the highest $(10.7 \%)$ and the lowest (5.1\%) level of infection, respectively. In other words, there was a significant correlation between species of fish and $L$. cyprinacea infection $(p<0.05)$.

The relationship between fish body length and L. cyprinacea infection was determined. Based on the obtained results, the highest prevalence of $L$. cyprinacea infection was observed in 
fish with a length of $5-8 \mathrm{~cm}(5.8 \%)$ and $2-5 \mathrm{~cm} \mathrm{(5.2 \% ),} \mathrm{and} \mathrm{the}$ lowest prevalence of $L$. cyprinacea infection was observed in fish with a length of more than $8 \mathrm{~cm}(1.9 \%)$. The analysis by the chisquare test showed that there was a significant relationship between fish size and infection prevalence (Table 2) $(P<0.05)$. Frequency distribution of $L$. cyprinacea infection in different organs was examined and the results are shown in Table 3. The highest and the lowest frequency of $L$. cyprinacea were observed in fins $(61.8 \%)$ and eyes $(0.5 \%)$, respectively, and this result was true for all collected fish.

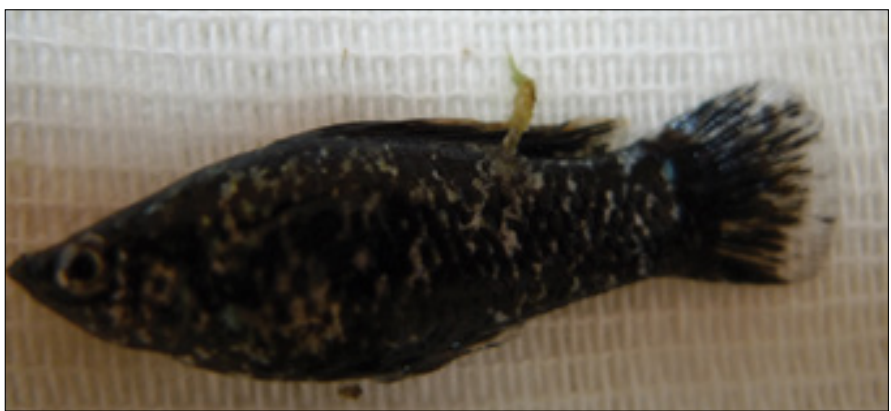

Figure 1. The Lernaea cyprinacea infection in Molly (P. latipinna) ornamental fish

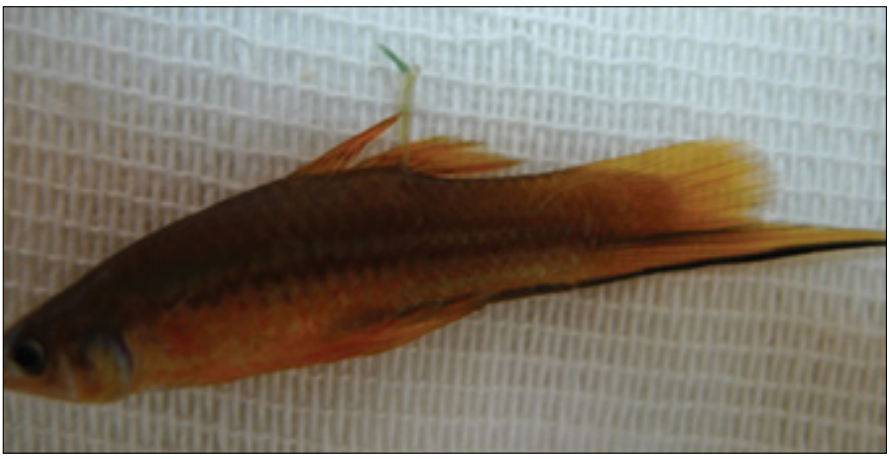

Figure 2. The Lernaea cyprinacea infection in Swordtail (X. helleri) ornamental fish

Table 1. Frequency distribution of $L$. cyprinacea infection in two species of Poeciliidae family ( $P$. latipinna and $X$. helleri)

\begin{tabular}{|l|c|c|c|}
\hline $\begin{array}{l}\text { Scientific } \\
\text { name } \\
\text { of the fish }\end{array}$ & $\begin{array}{c}\text { No. of } \\
\text { studied } \\
\text { fish }\end{array}$ & $\begin{array}{c}\text { No. of fish } \\
\text { infected with } \\
\text { L. cyprinacea }\end{array}$ & $\begin{array}{c}\text { Infection } \\
\text { percentage } \\
\text { (\%) }\end{array}$ \\
\hline P. latipinna & 3380 & 171 & 5.1 \\
\hline X. helleri & 140 & 15 & 10.7 \\
\hline Total & 3520 & 186 & 5.3 \\
\hline
\end{tabular}

As shown in Table 4, the prevalence and intensity of L. cyprinacea among fish collected in different seasons differed significantly from each other $(P<0.05)$. In this regard, the highest prevalence of $L$. cyprinacea infection was observed during summer, while no L. cyprinacea infection was observed during winter.

\section{Histopathologic Observations}

Histopathology revealed some lesions in the epidermis, dermis, and muscles. The epidermis was ulcerated and showed mild acanthosis and spongiosis around the parasite attachment sites. In the dermis, parasites were surrounded by chronic inflammatory reaction, and the sites of this reaction contained lymphocyte, histiocytes, and few eosinophils (Figure 3). In some cases, the embedded parasites induced fibrous tissue formation. Striated muscle fibers showed some degree of degeneration and necrosis. In some sections, presence of bacterial colonies as dark blue fine materials were noted (Figure 4). Other lesions included edema, congestion, and occasional hemorrhage.

\section{DISCUSSION}

There are 150 species of ornamental fish found in Iran, of which 40 are bred within Iran. In the present study, two species of ornamental fish were examined for $L$. cyprinacea infection.

Table 3. Frequency and percentage of $L$. cyprinacea infection in different organs of fish

\begin{tabular}{|l|c|c|}
\hline $\begin{array}{l}\text { The studied } \\
\text { organ }\end{array}$ & $\begin{array}{c}\text { Number of } \\
\text { collected parasites }\end{array}$ & $\begin{array}{c}\text { Prevalence of } \\
\text { infection (\%) }\end{array}$ \\
\hline Fins & 115 & 61.8 \\
\hline Gills & 52 & 28 \\
\hline Skin & 11 & 5.8 \\
\hline Mouth & 4 & 2.2 \\
\hline Eyes & 1 & 0.5 \\
\hline Other & 3 & 1.7 \\
\hline Total & 186 & 100 \\
\hline
\end{tabular}

Table 4. The prevalence of L. cyprinacea infection in different seasons

\begin{tabular}{|l|c|c|}
\hline Season & $\begin{array}{c}\text { Number of } \\
\text { studied fish }\end{array}$ & $\begin{array}{c}\text { Number and } \\
\text { percentage of } \\
\text { infected fish }\end{array}$ \\
\hline Fall & 1606 & $102(6.4 \%)$ \\
\hline Winter & 1297 & $0(0 \%)$ \\
\hline Spring & 447 & $17(3.8 \%)$ \\
\hline Summer & 170 & $67(39.4 \%)$ \\
\hline
\end{tabular}

Table 2. Frequency distribution of $L$. cyprinacea infection based on the size of the fish

\begin{tabular}{|l|c|c|c|c|c|}
\hline $\begin{array}{l}\text { Scientific name } \\
\text { of the } \\
\text { parasite }\end{array}$ & $\begin{array}{c}\text { No. of } \\
\text { studied } \\
\text { fish }\end{array}$ & $\begin{array}{c}\text { Body length } \\
\text { of groups } \\
\text { (cm) }\end{array}$ & $\begin{array}{c}\text { No. of studied } \\
\text { fish in } \\
\text { each group }\end{array}$ & $\begin{array}{c}\text { No. of infected } \\
\text { fish in } \\
\text { each group }\end{array}$ & $\begin{array}{c}\text { Prevalence of } \\
\text { infection in } \\
\text { each group (\%) }\end{array}$ \\
\hline L. cyprinacea & 3520 & $2-5$ & 1325 & 69 & 5.2 \\
\hline & & $5-8$ & 1928 & 112 & 5.8 \\
\hline
\end{tabular}




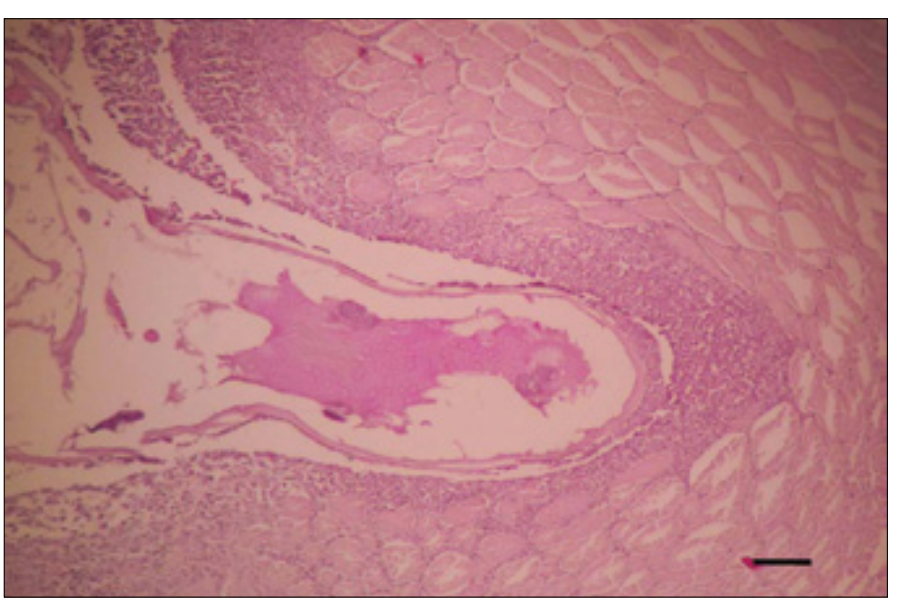

Figure 3. Parasite is surrounded by chronic inflammatory reaction, as observed by $\mathrm{H} \& \mathrm{E}$ staining. Bar $=100 \mu \mathrm{m}$

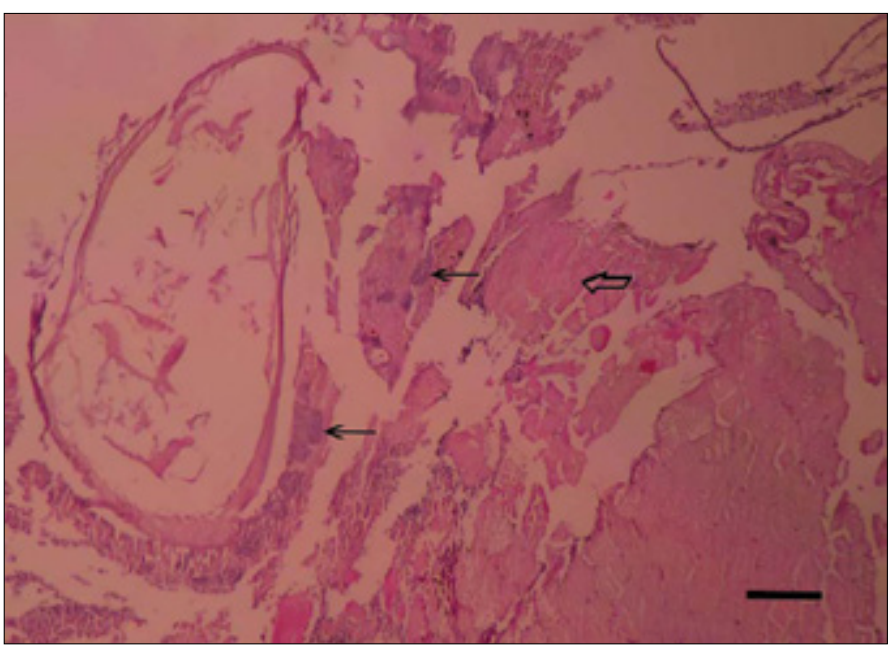

Figure 4. Degeneration and necrosis of striated muscle fibers and presence of bacterial colonies as dark blue fine materials (arrows), as observed by H\&E staining. Bar $=100 \mu \mathrm{m}$

Based on the results, from a total of 3520 fish of Poeciliidae family, 186 fish (5.3\%) were infected with L. cyprinacea, as shown in Table 1; the highest (10.7\%) and the lowest (5.1\%) level of infection were related to swordtails ( $X$. helleri) and mollies ( $P$. latipinna), respectively. This result is similar to that obtained in studies by Piazza et al. (11) and Kim et al. (12). In the study by Piazza et al. (11) on the ornamental fish P. latipinna and Xiphophorus maculatus, the level of Lernaea infection was $2.1 \%$. According to Kim et al. (12), the Lernaea infection among ornamental fish of Kyungki and Chungbuk, Korea, comprised a level of infection of $3.3 \%$ that was seen in P. latipinna. The parasite causes more problems for ornamental and aquarium fish than for other types of fish because it attaches to the skin of fish; this can affect the market friendliness and appearance of fish and can decrease the value of fish. Although the parasite can be removed using forceps, the wound becomes a site for viral, bacterial, and fungal infections, thereby resulting in the death of the fish. Variations in the prevalence of infection among different hosts may be because of the excessive contact between hosts and parasites, the difference in the manner in which the parasite attaches to the host, or the difference in immune responses of different hosts against the parasite, which has been mentioned in many previous reports (13). Severe lesions like bleeding, wound, and lymph nodes were observed on small fish. L. cyprinacea infection may have serious effects on fish health, particularly the health of small fish. This parasite can cause rupture and necrosis in areas such as the gill epithelium, while the attachment of the adult female L. cyprinacea causes bleeding, necrosis, muscle stiffness, inflammatory responses, and sometimes secondary bacterial infections. This is because the part of the $L$. cyprinacea that attaches to the skin deeply pierces the body of fish, thereby damaging their internal organs (4). As shown in Table 2, the relationship between fish size and infection intensity was significant $(P<0.05)$ because fish with lengths of $5-8 \mathrm{~cm}$ and 2-5 cm showed the highest level of $L$. cyprinacea infection, and fish with a length of more than $8 \mathrm{~cm}$ showed the lowest level of L. cyprinacea infection. These results conformed to the results of Barson et al. (14). This is because small fish and those fish with weak or undeveloped defense mechanism are easily attacked and infected by L. cyprinacea (14). In the present study, L. cyprinacea infection in different organs was examined and the results are shown in Table 3. The highest and the least frequency of $L$. cyprinacea were observed in fins (61.8\%) and eyes $(0.5 \%)$, respectively, and this result was consistent with that of GutiérrezGalindo and Lacasa-Millán (15). Based on the present study and the study by Gutiérrez-Galindo and Lacasa-Millán (2005), the infection of fins can be justified given that the fin is one of the organs that provides advantages for the parasite such as protection against water currents or abrasion; therefore, tissues of fin bases are easily pierced by the parasite (15). Regarding the studies conducted during different months, the highest level of infection was observed during summer because Lernaea spp. infects the fish only during the warm months. However, this crustacean is considered as one of the most prevalent pathogens in warm freshwater fish in Iran. However, the most important factor affecting the life cycle and pathogenesis of the parasite is temperature as the life cycle of the parasite is not completed at temperatures lower than $15^{\circ} \mathrm{C}(2,16)$. The prevalence of Lernaea spp. typically increases during the summer when water temperatures exceed $25^{\circ} \mathrm{C}$, although parasitized fish can be found during the fall and winter (16). As shown in Table 4, in the present study, the highest prevalence and the lowest prevalence of $L$. cyprinacea among ornamental fish were observed during summer and winter, respectively, which can be attributed to the temperature difference between the two seasons. In general, the elimination of $L$. cyprinacea from ornamental fish reproduction and breeding centers is probably impossible. Although L. cyprinacea infection is rather low in these centers, the warning of higher intensity of this infection in ornamental fish as well as in farmed fish in Iran must be considered because this parasite accompanies the fish throughout its life as well as lives with the fish in symbiosis and does not cause any problem for the fish. However, when adverse conditions such as poor nutrition, stress, lack of oxygen, and invasion of other pathogens occur, the balance between host and parasite is disturbed and the fish enters another phase and must be treated; otherwise, the disease progresses and the fish dies. Some chemical therapies are effective against crustacean parasites, particularly Lernaea spp. because 
chemical therapies can disturb their life cycle within a few weeks; however, they are less effective against the adult and nauplius parasites (4).

In the present study, the histopathologic findings of lerneosis, including ulceration, chronic inflammatory reaction, and fibrosis around the parasites, and the degeneration and necrosis of striated muscle fibers were similar to those found in previous surveys. The head of the sac-like female penetrates and is embedded into the body musculature as well as internal organs such as the liver and kidney. The embedded parasites induce ulcer development around the attachment, chronic inflammatory reaction, and eventually fibrosis around the head of the copepod $(17,18)$.

\section{CONCLUSION}

Considering the existing $L$. cyprinacea infection in ornamental fish reproduction and breeding centers of Kerman, management methods as well as physical and chemical treatments should be applied and made available to the possible customers to increase their knowledge and to inform them regarding the risk of infection and disease.

Ethics Committee Approval: Ethics Committee Approval was not received due to the nature of the study.

Informed Consent: Informed Consent is not required in this study.

Peer-review: Externally peer-reviewed.

Acknowledgements: The author is thankful to Dr. Reza Kheirandish and Mr. Hosein Khovand for their cooperation.

Conflict of Interest: No conflict of interest was declared by the author.

Financial Disclosure: This study was financially supported by Shahid Bahonar University of Kerman.

Etik Komite Onayı: Çalışmanın yapısından dolayı etik kurul onayına gerek duyulmamıştır.

Hasta onamı: Bu çalışma için hasta onamına gerek yoktur.

Hakem Değerlendirmesi: Dış Bağımsız.

Teşekkür: Yazar, Dr. Reza Kheirandish'e ve Hosein Khovand'a yardımlarından dolayı teşekkür eder.

Çıkar Çatışması: Yazarlar çıkar catışması bildirmemişlerdir.

Finansal Destek: Bu çalışma Kerman'ın Shahid Bahonar Üniversitesi tarafından finansal olarak desteklenmiştir.

\section{REFERENCES}

1. Klinger RE, Floyd RF. Introduction to freshwater fish parasites: University of Florida Cooperative Extension Service, Institute of Food and Agriculture Sciences, EDIS; 1998.
2. Roberts RJ, Shepherd CJ. Handbook of trout and salmon diseases: Fishing News (Books) Ltd.; 1974.

3. Ho J. Cladistics of the Lernaeidae (Cyclopoida), a major family of freshwater fish parasites. Journal of marine systems 1998; 15: 177-183. [CrossRef]

4. Lester RJG, Hayward CJ. Phylum Arthropoda. In: Fish diseases and disorders, ol 1: Protozoan and Metazoan Infections. 2nd edition, ed., Woo PTK. London: CAB International; 2006. p. 466-65. [CrossRef]

5. Kır I. The Effects of Parasites on the Growth of the Crucian Carp (Carassius carassius L., 1758) Inhabiting the Kovada Lake. Turkiye Parazitol Derg 2007; 31: 162-6.

6. Adams AM. Infestation of Fundulus kansae (Garman) (Pisces: Cyprinodontidae) by the Copepod Lernaea cyprinacea Linnaeus, 1758, in the South Platte River, Nebraska. American Midland Naturalist 1984: 131-7. [CrossRef]

7. Jalali B, Barzegar M. Fish parasites in Zarivar lake. J Agric Sci Technol 2006; 8: 47-58.

8. Robinson J, Avenant-Oldewage A. Aspects of the morphology of the parasitic copepod Lernaea cyprinacea Linnaeus, 1758 and notes on its distribution in Africa. Crustaceana 1996: 610-26. [CrossRef]

9. des Clers S. Functional relationship between sealworm (Pseudoterranova decipiens, Nematoda, Ascaridoidea) burden and host size in Atlantic cod (Gadus morhua). Proc Biol Sci 1991; 245: 85-9. [CrossRef]

10. Yamaguti S. Parasitic Copepoda and Branchiura of Fishes. New York, London, and Sydney: Interscience Publishers; 1963.

11. Piazza RS, Martins ML, Guiraldelli L, Yamashita MM. Parasitic diseases of freshwater ornamental fishes commercialized in Florianópolis, Santa Catarina, Brazil. Boletim do Instituto Pesca 2006; 32: 51-7.

12. Kim JH, Hayward CJ, Joh SJ, Heo GJ. Parasitic infections in live freshwater tropical fishes imported to Korea. Dis Aquat Organ 2002; 52: 169-73. [CrossRef]

13. Bond N. Observations on the effects of the introduced parasite Lernaea cyprinacea on a lowland population of a small native Australian fish, mountain galaxias Galaxias olidus. Victorian Naturalist 2004; 121: 194-8.

14. Barson M, Mulonga A, Nhiwatiwa T. Investigation of a parasitic outbreak of Lernaea cyprinacea Linnaeus (Crustacea: Copepoda) in fish from Zimbabwe. African Zoology 2008; 43: 175-83. [CrossRef]

15. Gutiérrez-Galindo J, Lacasa-Millán M. Population dynamics of Lernaea cyprinacea (Crustacea: Copepoda) on four cyprinid species. Dis Aquat Organ 2005; 67: 111-4. [CrossRef]

16. Durham BW, Bonner TH, Wilde GR. Occurrence of Lernaea cyprinacea on Arkansas River shiners and peppered chubs in the Canadian River, New Mexico and Texas. Southwest Nat 2002; 47: 95-8. [CrossRef]

17. Roberts RJ. Fish pathology: Wiley-Blackwell; 2012.

18. El-Galil MAAA, ESSA MAA, Korni FMM. Studies on Lernaeosis and the efficacy of Dipterex as treatment in the Hatchery Reared Fingerlings of Cyprinids. Journal of American Science 2012; 8: 574-80. 